\title{
FATHERS WITH HIGHLY DEMANDING PARTNERS AND OFFSPRING IN A SEMIDESERT ENVIRONMENT: ENERGETIC ASPECTS OF THE BREEDING SYSTEM OF MONTEIRO'S HORNBILLS (TOCKUS MONTEIRI) IN NAMIBIA

\author{
Marcel Klaassen, ${ }^{1,5}$ Alex BrenninKmeijer, ${ }^{2}$ Christian Boix-Hinzen, ${ }^{3}$ and \\ JOHN MENDELSOHN ${ }^{4}$ \\ ${ }^{1}$ Netherlands Institute of Ecology (NIOO-KNAW), Rijksstraatweg 6, 3631 AC Nieuwersluis, The Netherlands; \\ ${ }^{2}$ Altenburg and Wymenga Ecological Bureau, P.O. Box 32, 9269 ZR Veenwouden, The Netherlands; \\ ${ }^{3}$ Percy FitzPatrick Institute of African Ornithology, University of Cape Town, Rondebosch 7701, \\ Cape Town, South Africa; and \\ ${ }^{4}$ P.O. Box 80044, Olympia, Windhoek, Namibia
}

\begin{abstract}
Aвstract.-Molting females of Monteiro's Hornbills (Tockus monteiri) seal themselves in nest cavities to breed until chicks are about half grown. To gain insight into the chronology of energy requirements of the Monteiro's Hornbill family unit in relation to this peculiar breeding strategy, we measured a number of ecological, physiological, and environmental variables during the Monteiro's Hornbill's breeding season. Those measurements included rates of energy expenditure of female Monteiro's Hornbills while in the nest cavity, characterizing their thermal environment, timing of egg laying, molt, hatching and fledging of chicks, as well as measuring clutch size and chick growth. Temperatures within the nest box varied between 12 and $39^{\circ} \mathrm{C}$ and did not affect the female energy expenditure. Female body mass and energy expenditure averaged $319 \mathrm{~g}$ and $5 \mathrm{~W}$, respectively, at the start of concealment and decreased by on average $1.1 \mathrm{~g} \mathrm{day}^{-1}$ and $0.05 \mathrm{~W}$ day $^{-1}$ during at least the first 30 days of the 52-58 day concealment period. Clutch size varied between 1 and 8 and averaged 4.1 eggs, with eggs averaging only $66 \%$ of the mass predicted for a bird of this size. Over the range of chick ages at which the female might leave the nest, the predicted energy requirements for maintenance and tissue growth for a Monteiro's Hornbill chick increase sharply from $1.2 \mathrm{~W}$ at age 8 to $3.0 \mathrm{~W}$ at age 25. Reduction of the female energy requirement with time, the relatively low growth rate and therewith low energy requirements of Monteiro's Hornbill chicks, and an appropriate timing of the female's exodus from the nest cavity all aid in containing peak energy demands to levels that are sustainable for the food provisioning male. Received 1 May 2002, accepted 23 April 2003.
\end{abstract}

Résumé.-Les femelles en mue du Calao de Monteiro (Tockus monteiri) s'enferment dans les cavités où elles nidifient jusqu'à ce que les poussins aient atteint la moitié de leur développement. Pour mieux comprendre la chronologie des besoins énergétiques de la famille de Calao de Monteiro en relation avec cette singulière stratégie de reproduction, nous avons mesuré différentes variables écologiques, physiologiques et environnementales au cours de la saison de reproduction du Calao de Monteiro. Ces mesures incluent la dépense énergétique des femelles de Calao de Monteiro durant leur claustration, la caractérisation de leur environnement thermique, la cinétique de la ponte, de la mue, de l'éclosion et du développement du plumage des poussins, ainsi que le nombre d'œufs et la croissance des poussins. La température à l'intérieur des nichoirs a varié entre 12 et $39^{\circ} \mathrm{C}$ et n'a pas affecté les dépenses énergétiques des femelles. La masse corporelle des femelles et leurs dépenses énergétiques ont été en moyenne de $319 \mathrm{~g}$ et $5 \mathrm{Watt}$, respectivement, au début de la claustration et ont diminué en moyenne de $1.1 \mathrm{~g} /$ jour et 0.05 Watt/jour pendant au moins les 30 premiers jours des $52-58$ jours de la période de claustration. Le nombre d'œufs a varié entre 1 et 8 et a été en moyenne de 4.1 , leur masse atteignant en moyenne seulement $66 \%$ de la masse prédite pour un oiseau de cette taille. Pour la gamme d'âges des poussins auxquels la femelle est susceptible de quitter le nid, les besoins énergétiques prédits pour l'entretien et la croissance des tissus d'un poussin de Calao de Monteiro augmentent brusquement de 1.2 Watt à l'âge de 8 jours à 3.0 Watt à l'âge de 25 jours. La diminution des besoins énergétiques de la femelle au cours du temps, le taux de croissance relativement faible, et de ce fait les faibles besoins énergétiques des poussins du Calao de Monteiro, et l'abandon du nid par la femelle au moment opportun, sont autant de facteurs qui permettent de restreindre la demande énergétique à un niveau compatible avec l'approvisionnement en nourriture par le mâle.

\footnotetext{
${ }^{5}$ E-mail: m.klaassen@nioo.knaw.nl
} 
HORNBILls (BUCEROTIDAE) EXHIBIT a very peculiar breeding habit wherein females seal themselves into the nest cavity by closing off the cavity entrance with a plug made out of mud and feces (Kemp 1995). Male assistance in that effort varies among species, but is generally limited to provisioning additional mud, some millipedes, and nest-lining material. In Monteiro's Hornbill (Tockus monteiri), the breeding female remains concealed for up to 6-9 weeks, spanning egg laying, incubation, and part of the nestling rearing period. For the entirety of that period, the male is responsible for providing the entire female and offspring's nutritional requirements, doing so by transferring food to the female through a small, vertical slit that is retained in the nest plug. The female's nutritional needs are further exacerbated by her simultaneous molts of all flight feathers, an energetically costly process (Klaassen 1995).

The sealed nest cavity of hornbills probably promotes very low nest predation rates. From an energetic viewpoint, however, it is not an obviously beneficial breeding strategy. Presumably a high evolutionary pressure exists on animals to economize energy use to increase fitness (Drent and Daan 1980). Accordingly, one may wonder how and why the apparently extravagant breeding biology of hornbills could have evolved: the male finds himself confronted with a huge work load for much of the breeding season in caring for the reproductive and molting needs of his reclusive partner as well as their offspring. This breeding strategy seems to be in disagreement with current hypotheses purporting conservative energy use by low latitude birds and mammals. Animals from low latitudes often face low or unpredictable food availability (Thiollay 1991, Lovegrove 1996, Boix-Hinzen and Lovegrove 1998) and would benefit from reduced rates of metabolic heat production to avoid heat stress (Weathers 1979, Ellis 1984, Klaassen and Drent 1991, Klaassen 1995). Given those notions on the energetics of low-latitude birds, it is of interest to examine the energetic requirements of hornbill families to gain functional understanding of their unusual breeding biology.

We accordingly measured the energy expenditure of incubating female Monteiro's Hornbills by recording oxygen consumption in the nest. Additionally, data on the timing of egg laying, molt, hatching and fledging of chicks, as well as clutch size and chick growth rates were obtained to provide insight into chronology of the energy requirements of the Monteiro's Hornbill's family unit over the course of the breeding season.

\section{Methods}

The study was conducted in Daan Viljoen Game Reserve situated $20 \mathrm{~km}$ west of Windhoek, Namibia, in the Khomas Hochland hills (22 $30^{\prime} \mathrm{S}, 16^{\circ} 58^{\prime} \mathrm{E}$; $1,560 \mathrm{~m}$ above sea level). The vegetation in the area is highland savanna characterized by tree species such as Acacia reficiens, A. erubescens, and Combretum apiculatum, whereas along river courses $A$. erioloba, A. karroo, Ziziphus mucronata, and Rhus lancea predominate. Hornbills only breed after rainfall, which is $\sim 350 \mathrm{~mm}$ annually, yet highly variable. A project on breeding biology of hornbills was started in this area in 1984. By 1996, a total of 80 nest boxes suitable for Monteiro's Hornbills were installed, which has created an exceptionally dense breeding population of Monteiro's Hornbills in the Daan Viljoen Game Reserve. Whereas breeding densities for Monteiro's Hornbills normally range between 0.10 and 0.21 pairs $\mathrm{km}^{-2}$ (Kemp 1995), breeding densities in Daan Viljoen Game Reserve may be $10 \times$ higher in some years. Volume of those nest boxes is $\sim 15 \mathrm{~L}$ and typically measured $18 \times 17 \times 50 \mathrm{~cm}$. Birds reduced the effective size of the nest boxes to 7-11 L due to accumulation of nest material.

As part of the hornbill project, Daan Viljoen Game Reserve's nest boxes were checked during the months December-May 1984, 1989, 1990, 1992-1994, and 1996. During the breeding season, at varying intervals nest boxes were visited (though $65 \%$ of all visits daily and $90 \%$ of all visits within six days) and their contents examined by removing the top lid. The mass of newly laid eggs $( \pm 0.1 \mathrm{~g})$, and chick and female body-mass $( \pm 1 \mathrm{~g})$ was measured using Pesola spring balances. In adult females, central tail feather length (tail, $\pm 1 \mathrm{~mm}$ ) was measured with a ruler. Egg masses were only recorded in 1992 (57 eggs in 14 clutches) and 1993 (122 eggs in 24 clutches). In 1984, 261 body-mass measurements of 12 Monteiro's Hornbill chicks from three nests were taken. In 1992, a total of 689 body masses of 71 chicks from 19 nests were registered. Morphometric measurements on females were conducted in all years except 1984 .

In addition to the measurements described above, oxygen consumption of 34 incubating female Monteiro's Hornbills was measured at randomly selected times of day from 21 February until 14 March during the 1996 breeding season. All measurements were conducted in the field using a portable indirect calorimeter system and modified nest boxes to act as metabolic chambers. The portable indirect calorimeter system consisted of a battery driven $12 \mathrm{~V}$ pump (KNF 
Neuberger, Frieburg, Germany), a 1357 Brooks ShoRate flow meter (Brooks Instrument, Veenendall, The Netherlands), and a battery driven Servomex 570A oxygen analyzer (Servomex Group, Crowborough, United Kingdom). Air from the nest box passed through a $1.5 \mathrm{~L}$ silica gel drying tube before being sampled for oxygen content.

After arrival at a nest site, we activated the respirometry system and drew ambient air through the oxygen analyzer for approximately half an hour. That provided a stable reading of oxygen concentration in the outside air. Meanwhile the nest box was carefully removed from the tree and quickly (within $15 \mathrm{~min}$ ) transformed into an airtight metabolic chamber using heavy-duty plastic bags and duct tape. The entrance was sealed with a transparent plastic sheet to maintain the original light levels inside the box. The inlet of the hose leading from the nest box to the indirect calorimeter was positioned just in front of, and in a few cases, through the entrance slit of the nest box. A tiny hole was made at the rear of the next box near the base to serve as an air inlet. After switching from outside air to air from the nest box, half an hour was needed to stabilize the system. A calibrated thermistor was placed below the top lid of the box for measurement of nest-box temperature $\left( \pm 0.05^{\circ} \mathrm{C}\right)$. The nest box was subsequently replaced in its original position or, to reduce handling time, in exactly the same orientation at the bottom of the tree as when attached to the tree. Air was drawn from that improvised metabolic chamber at a constant and moderate airflow between 42-47 $(n=6)$ or 89-101 $(n=28) \mathrm{L} \mathrm{h}^{-1}$ corrected to STPD assuming a local stable air pressure of $850 \mathrm{hPa}$ (E. van der Zee Windhoek Meteorological Station pers. comm.). Each minute a temperature and oxygen concentration reading was automatically recorded to a Squirrel 1252 data logger (Grant Instruments, Cambridge, United Kingdom). Oxygen consumption measurements lasted $1.5 \mathrm{~h}$ $( \pm 1 \mathrm{~h})$, after which an additional ambient air sample was again passed through the system for half an hour to get a final reference sample of inlet air. Following oxygen consumption measurements, content of the nest box was inspected for presence of eggs and female morphometrics were taken. Subsequently, the nest box was unwrapped and placed in its original position at the tree. Some of the Monteiro's Hornbill females started screaming when we handled the nest box, yet all except for one became quiet as soon as we had finished installing the equipment. Rates of oxygen consumption were calculated as the mean value of all measurements taken over the entire measurement period. Measurements where the variation in oxygen consumption over the measuring period was large (SD $>20 \%$ of mean) were omitted from the analyses ( $n=2$; also including the screaming individual). Oxygen consumption was calculated according to Klaassen et al. (1997) assuming a respiratory quotient of 0.71 (i.e. assuming the bird catabolized fat and protein). Energy expenditure was calculated using a conversion efficiency of $19.6 \mathrm{~kJ} \mathrm{~L}^{-1} \mathrm{O}_{2}$ consumed (Gessaman and Nagy 1988).

In addition, to study in more detail possible daily variation in oxygen consumption, one female was subjected to an oxygen-consumption trial lasting $19 \mathrm{~h}$, outside air being drawn through the system for 30 min every $1-2 \mathrm{~h}$ of measurement after which a $1 \mathrm{~h}$ stabilization period followed before measurements were resumed. Of this long-duration measurement, only the first of the six measurement periods was used for comparison with the measurements on the other Monteiro's Hornbill females.

Thirteen individuals in this study on which incubation energy expenditure was measured were concomitantly used for a paternity analysis study (Stanback et al. 2002). Within $12 \mathrm{~h}$, laid eggs were removed and in three cases replaced with similar-sized plastic dummy egg replicas.

To acquire a better understanding of the thermal environment of incubating Monteiro's Hornbills, we measured daily temperature profiles in three occupied nest boxes for 24-h periods and one of those for five more days, during the 1996 breeding season. A thermistor was placed under the top lid of those nest boxes and temperatures were measured at $15 \mathrm{~min}$ intervals and stored on a Squirrel 1252 data logger. Coincident ambient temperatures were obtained from atmospheric temperature registrations measured at the meteorological station in Windhoek, Namibia, $14 \mathrm{~km}$ from the study site.

All statistics were performed using STATISTICA 5.5 (StatSoft, Tulsa, Oklahoma). Logistic growth curves were fitted to the chicks' body mass data using a nonlinear estimation procedure. The logistic growth curve was used as the basis for a tentative estimation of the energy requirements of growing hornbill chicks. Those requirements were assumed to consist solely of resting energy expenditure and tissue energy deposition. Other energy costs associated with chick growth (activity and thermoregulatory costs) are probably negligible in this hole-nesting low-latitude species (Weathers 1996) at least for the first half of the nestling period (Klaassen 1994). The chick's resting energy expenditure was estimated from the chick's body mass using equations 2 and 5 in Weathers and Siegel (1995), in combination with the average body mass of adult females. The tissue energy deposition was estimated by multiplying the body mass increase with age with the mass specific tissue energy density according to Weathers (1996; $3.51+4.82 \times$ body mass /asymptotic body mass).

Energy expenditure of incubating female hornbills was analyzed in relation to time of day (day or night), treatment (eggs removed $[n=10]$ vs. clutch intact or original eggs replaced with plaster eggs $[n=$ 22]), clutch size, stage of molt (i.e. central tail feather length; for the one newly concealed individual still having its old tail, central tail feather length was set to 
zero), nest-box temperature, square of nest-box temperature, and body mass using backward multiple regression and analysis of covariance.

Using body-mass data for all females over all years, we investigated whether body mass changed during concealment. Only data for individuals with multiple measurements per breeding season were used. To correct for individual and across-year variation, body mass was analyzed in relation to days since voluntary concealment using analysis of covariance with year $x$ individual as random factor.

\section{Results}

Ambient temperature varied between 13 and $35^{\circ} \mathrm{C}$ at Windhoek Meteorological Station during the 1996 research period (Fig. 1). The range of temperatures measured in three different nest boxes over one- to six-day periods was slightly wider, ranging from 12 to $39^{\circ} \mathrm{C}$.

Clutch size of nests studied in 1996 varied between 1 and 8 and averaged 4.1 eggs (SD = $1.6, n=38)$. The mass of the eggs varied between 11.7 and $18.5 \mathrm{~g}$ and averaged $15.4 \mathrm{~g}(\mathrm{SD}=1.4$, $n=176)$, being only $66 \%$ of the predicted mass for birds of that size (Rahn et al. 1975).

Growth rate of chicks (Fig. 2) fitted a logistic growth function very well $\left(r^{2}=0.886\right)$. The calculated daily energy requirements for resting and growth rapidly increase over the first three weeks of life and remain stable (Fig. 2). Over the range of chick ages at which females are known to first leave nests, predicted energy requirements of a Monteiro's Hornbill chick for resting and tissue growth combined increase from $1.2 \mathrm{~W}$ at age 8 days to $3.0 \mathrm{~W}$ at age 25 days.

Analysis of covariance (ANCOVA) showed that the energy expenditure of incubating fe-

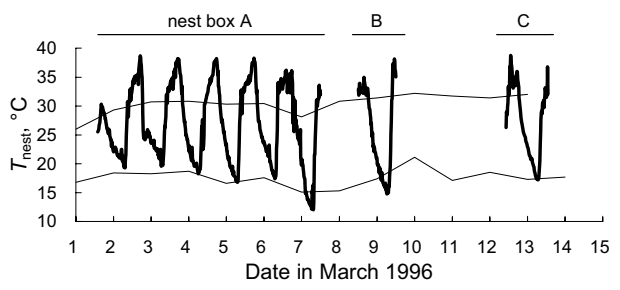

FIG. 1. Ambient and nest-box temperatures during March 1996. Thin lines: minimum and maximum temperatures at Windhoek Meteorological Station during the period of measurements of oxygen consumption in 1996. Heavy lines: daily variations in temperature in three different nest boxes (A, B, and C) with incubating females.

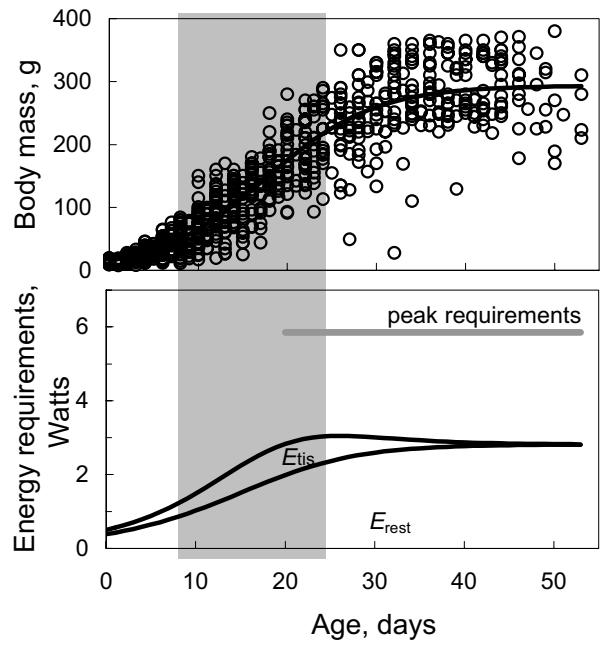

FIG. 2. Body mass (upper panel) and predicted energy requirements (lower panel) in relation to age for Monteiro's Hornbill chicks. A logistic growth curve was fitted to the body mass data (body mass = $\left.293.5 /\left[1+18.0 \mathrm{e}^{-0.164 \text { age }}\right]\right)$. The shaded area indicates the period in which the female leaves the nest (Kemp 1995). Energy requirements in part consist of resting energy expenditure ( $E_{\text {rest }}$, Watts) and tissue deposition ( $E_{\text {tis }}$, Watts), which are cumulatively presented. The predicted peak energy requirements for a Monteiro's Hornbill chick is indicated.

male hornbills was neither affected by time of day nor by the treatment of the various clutches (ANCOVA with clutch size, central tail feather, nest-box temperature, square of nestbox temperature, and body mass as covariates; effect of time of day: $F=0.51, \mathrm{df}=1$ and $24, P=$ 0.481; effect of treatment: $F=0.10, \mathrm{df}=1$ and $24, P=0.810)$. Removing all factors from the analysis and conducting backward multipleregression analysis on the remaining covariates only revealed stage of molt (i.e. central tail feather length) to have a significant effect (Fig. 3) on energy expenditure of the incubating female. Stage of molt has a high correspondence with duration of incubation. In a reduced major-axis analysis of central tail-feather length versus number of days since the first egg was laid, central tail-feather growth rate was estimated at $3.8 \mathrm{~mm} \mathrm{day}^{-1}\left(n=29, r^{2}=0.929, P<\right.$ 0.001). Because stage of molt has a high correspondence with duration of incubation, age of clutch was equally inversely correlated with energy expenditure of incubating females $(n=$ $\left.29, r^{2}=0.229, P=0.009\right)$. Thus, with duration of 


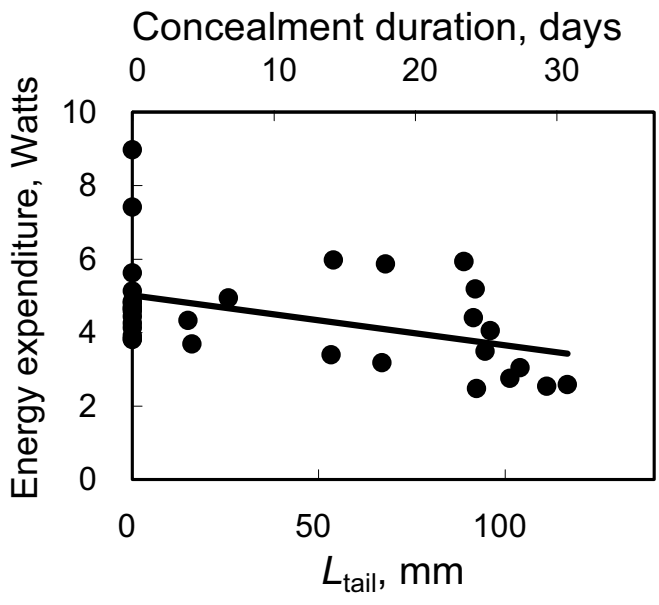

FIG. 3. Energy expenditure during incubation $\left(E_{\text {inc }^{\prime}}\right.$ Watts) of Monteiro's Hornbill females in relation to stage of molt (central tail feather length, $L_{\text {tail }^{\prime}}$ millimeters; $E_{\text {inc }}=5.014-0.014 \mathrm{~L}_{\text {tail }} ; n=32, r^{2}=0.191, P=$ 0.012 ). Along the upper abscissa, duration of concealment is indicated, which was calculated using $3.8 \mathrm{~mm}$ central tail feather growth/days (see text).

concealment females spend less energy. Among females examined for oxygen consumption in 1996, no variation in body mass during the course of the breeding season was apparent ( $n$ $\left.=29, r^{2}=0.001, P=0.884\right)$. However, using all repeat female body-mass measurements from all years and controlling for individual and among-year variation (by including year $\times$ individual as random factor) a clear body-mass decrease was apparent with concealment duration of $1.1 \mathrm{~g} \mathrm{day}^{-1}$ (Fig. 4). Continuous measurement of oxygen consumption in one incubating female (Fig. 5) showed no signs of a daily rhythm in energy expenditure.

\section{DisCUSSION}

The predicted basal metabolic rate during the resting phase for nonpasserines with an average body mass of $319 \mathrm{~g}$ is $1.94 \mathrm{~W}$ (Daan et al. 1989). Predicted thermal conductance for a bird of this size during the resting phase is $0.058 \mathrm{~W}^{\circ} \mathrm{C}^{-1}$ (Aschoff 1981). Assuming a body temperature of $40^{\circ} \mathrm{C}$, the lower critical temperature for such a bird would amount to $([40 \times 0.058-1.94]$ / $0.058=) 6.6^{\circ} \mathrm{C}$. Predicted lower critical temperature for Monteiro's Hornbills is thus well below the lowest nest-box temperature recorded. One may expect the true lower critical temperature

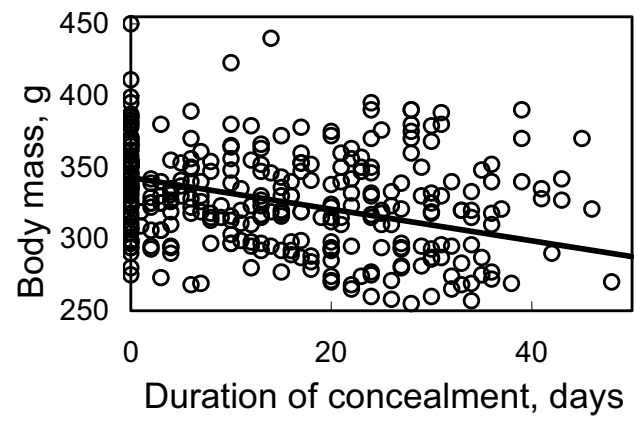

Fig. 4. Body mass of female Monteiro's Hornbills $(M$, grams) in relation to duration of concealment $(t$, day). ANCOVA with individual $\times$ year, $n=83$, as random factor; $n=321, r^{2}=0.206, P<0.001 ; M=$ 343-1.1 $t$

of the concealed and molting female Monteiro's Hornbill to be higher than predicted due to reduced insulation associated with molt, a somewhat lower energy expenditure than predicted (see below), and extra thermoregulating costs of incubation. However, the additional energetic costs for incubation on top of the resting costs are probably low (Williams 1996) and the reduced insulation as a result of molt is probably very moderate (Schieltz and Murphy 1997). In addition, the material in the nest box might provide extra insulation (Buttemer et al. 1987). Thus, it is very likely that the Monteiro's Hornbill females in our study were rarely if ever cold stressed. On the upper end of the nest-box temperature range, hornbills might have faced a thermoregulatory challenge, with nest-box temperatures sometimes approaching body temperature. However, tropical species seem to be more adapted to exploiting hyperthermia as a mechanism to contend with heat stress than nontropical species (Weathers 1997). In any case, an effect of temperature on energy expenditure measurements of the females was not apparent. We therefore conclude that the thermal environment of the birds was within their thermal neutral zone for most of the time.

During the course of her stay in the nest, we measured a decrease in female energy expenditure by as much as $33 \%$. That reduction might become even more substantial later on during her concealment in the nest because we only conducted measurements during the first half of her voluntary imprisonment up until hatching of the first chicks. Although 


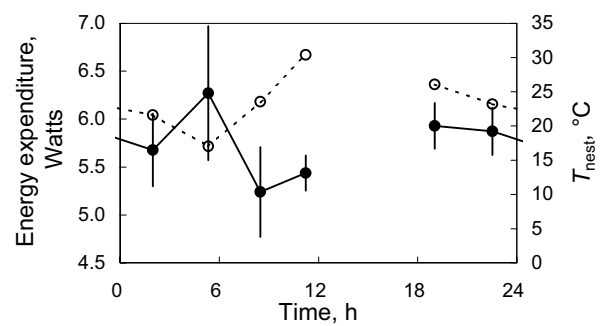

FIG. 5. Average energy expenditure for each period of measurement ( $\pm \mathrm{SD}$, closed dots) and temperature in the nest box (open dots) in relation with time of day for an incubating Monteiro's Hornbill in nest C42 from the evening of 29 February 1996 until noon the next day.

we did not note any significant body-mass reduction in our sample of females used for measurements of energy expenditure, a daily body-mass decrease during concealment was noticeable in a larger sample using all repeated female body-mass measurements over the years of study. With her forced immobility in the nest box, the female conceivably has less use for much of her functional tissues-such as muscles-and might subsequently reduce their size, function, or both. This slimming of specific tissues might also bring about a reduction in energy expenditure (e.g. Chappell et al. 1999). Flexibility of the "metabolic machinery" of organisms, for which probably an example in female hornbills is presented here, has only recently gained interest in life-history studies (Piersma and Lindström 1997). Whether or not the slimming of functional tissues is a special physiological adaptation in hornbills is questionable. Without appropriate training, most animal tissues reduce in size. In any case, that reduction in female energy expenditure over time will clearly benefit the male and the family as a whole. By reducing her energy expenditure, he can either forage less or give his offspring a larger share of the food he brings in. A further lowering of the energy requirements of the family unit would be achieved by low daily energy requirements of the young. Growth rate affects those requirements through its effects on requirements for tissue synthesis and deposition. Growth rate of Monteiro's Hornbill chicks are exactly as predicted for tropical land birds showing a $30 \%$ slower growth rate than predicted for birds from temperate latitudes (Ricklefs

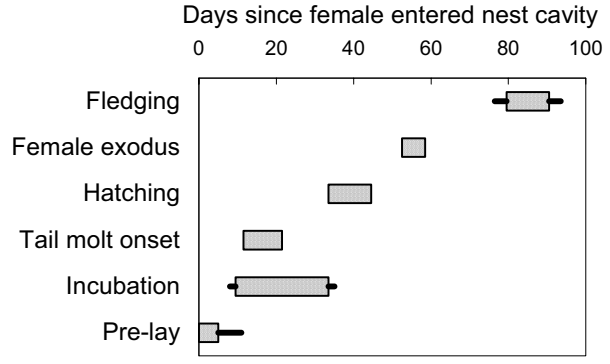

FIG. 6. Timing of egg laying, incubation, molt, hatching, fledging, and the female nest exodus relative to the moment the female entered the nest. For the prelaying, incubation, and fledging periods the most extreme observations are indicated by black bars. Data from this study and Kemp (1995).

1976). However, that slow growth rate is also expected to reduce resting energy expenditure as was found in an interspecific comparison of hatchling birds (Klaassen and Drent 1991) and intraspecifically in Arctic Tern (Sterna paradisaea) chicks (Klaassen and Bech 1992). Resting energetic costs of the chicks depicted in Figure 2 are not corrected for the typically low growth rate of Monteiro's Hornbill chicks and might thus be overestimated.

Total energy requirements of the chick are not only composed of the energetic costs for resting and tissue growth, but include activity and thermoregulatory costs. Thermoregulatory costs are presumably low, given the prevailing temperature conditions, the heat production of the female during early development, and the energy savings associated with huddling (e.g. Boix-Hinzen and Lovegrove 1998). Typically, activity costs, which are not included in Figure 2 , start to become important during the second half of the developmental period and may then be substantial (Klaassen 1994, Weathers 1996). The peak energy requirements of a chick thus occur towards the end of the developmental period after two-thirds of the nestling period. Peak energy requirements for chicks of the size and growth rate of Monteiro's Hornbill chicks are predicted to be $6.9 \mathrm{~W}$ (Weathers 1996). However, Weathers (1996) noted that the few tropical species included in his data set typically exhibited peak energy requirements $15 \%$ below those predicted. That is probably not only due to low thermoregulatory costs in tropical compared to high latitude chicks, but also to a lower resting energy expenditure associated with 
their low growth rates. Adjusting predicted energy needs for Monteiro's Hornbill chicks with the same percentage results in an estimation of $5.8 \mathrm{~W}$ for the peak energy requirements (Fig. 2). Still, predicted peak requirements of a single chick are much higher than the requirements of the adult female. The leaving of the nest by the female before the peak requirements of the nestlings are reached is probably not only important to alleviate peak energy demands on her male partner but also to assist him in the provisioning of their nestlings (Kemp 1995).

Given changes in energy requirements throughout the breeding period for young and female, scheduling of female nest exodus influences energy requirements of the whole family unit. In Figure 6, an attempt is made to compile the breeding season's schedule for Monteiro's Hornbills depicting the timing for a number of the most characteristic events for this stage in the yearly cycle. It shows that the female leaves the nest before nestlings are halfway through their nestling period. Thus, the female leaves the nest before peak requirements of the brood are reached (cf. Fig. 2). The same phenomenon is also found in some semialtricial birds, where the chicks are left unattended from approximately halfway through development when their energy requirements are rapidly increasing (Klaassen 1994, Stienen and Brenninkmeijer 1999). Thus, the progressive reduction in the energy requirements of the confined female, the low rate of energy demand attendant with low growth rates of Monteiro's Hornbill chicks, and the careful scheduling of female molt and nest exodus collectively ameliorate the peak energy demands of the family unit and the consequent workload on the male. Nevertheless, the male's workload for his family seems disproportionately high, yet seems to be compensated by a high paternity insurance (Stanback et al. 2002). Given that Monteiro's Hornbill is a truly monogamous species, it may be advantageous to reduce the total family costs wherever possible, an endeavor to which this peculiar breeding strategy may contribute by low female maintenance costs while in the nest.

\section{ACKNOWLEDGMENTS}

In the course of the 1984-1996 field seasons C. Brown, K. Chung, C. Clinning, J. Karubian, N. Popkin, B. Rieckert, H. Riehmer, and M. Stanback have assisted in gathering data. We thank R. Simmons of the
Ministry of Environment and Tourism and the staff of Daan Viljoen Game Reserve for their support during the fieldwork, which was also greatly facilitated by P. Eisselein who provided an easy access road into the reserve. Servomex Holland made the portable oxygen analyzer available for the duration of the 1996 field season. Other major components of the oxygen analyzer set up were supplied by Alterra, Wageningen, The Netherlands. Meteorological data were kindly provided by the Windhoek Meteorological Station. B. Buttemer and two anonymous reviewers made valuable improvements on the manuscript. The work was financially supported by a Netherlands Foundation for the Advancement of Tropical Research (NWOWOTRO) grant to M.K. This is publication 3150 of the Netherlands Institute of Ecology (NIOO-KNAW), Center for Limnology, and publication number 330 of the Center for Wetland Ecology.

\section{Literature Cited}

Aschoff, J. 1981. Thermal conductance in mammals and birds: Its dependence on body size and circadian phase. Comparative Biochemistry and Physiology 69:611-619.

Boix-Hinzen, C., And B. G. Lovegrove. 1998. Circadian metabolic and thermoregulatory patterns of Red-billed Woodhoopoes (Phoeniculus purpureus): The influence of huddling. Journal of Zoology (London) 244:33-41.

Buttemer, W. A., L. B. Astheimer, W. W. Weathers, AND A. M. HaYWORTH. 1987. Energy savings attending winter-nest use by Verdins (Auriparus flaviceps). Auk 104:531-535.

Chappell, M. A., C. BeCH, and W. A. Buttemer. 1999. The relationship of central and peripheral organ masses to aerobic performance variation in House Sparrows. Journal of Experimental Biology 202:2269-2279.

DaAn, S., D. Masman, A. StrijKstra, and S. Verhulst. 1989. Intraspecific allometry of basal metabolic rate: Relations with body size, temperature, composition and circadian phase in the kestrel, Falco tinnunculus. Journal of Biological Rhythms 4:267-284.

DRENT, R. H., AND S. DAAN. 1980. The prudent parent: Energetic adjustments in avian breeding. Ardea 68:225-252.

ELLIS, H. I. 1984. Energetics of free-ranging seabirds. Pages 203-234 in Seabird Energetics (G. C. Whittow, and H. Rahn, Eds.). Plenum, New York.

Gessaman, J. A, And K. A. Nagy. 1988. Energy metabolism: Errors in gas-exchange conversion factors. Physiological Zoology 61:507-513.

Kemp, A. C. 1995. The Hornbills. Oxford University Press, Oxford.

KlaAsSen, M. 1994. Growth and energetics of tern 
chicks from temperate and polar environments. Auk 111:525-544.

KlaAsSen, M. 1995. Moult and basal metabolic costs in males of two subspecies of stonechats: The European Saxicola torquata rubicula and the East African S. t. axillaris. Oecologia 104: 424-432.

KlaAssen, M., and C. BeCh. 1992. Resting and peak metabolic rates of Arctic Tern nestlings and their relations to growth rate. Physiological Zoology 65:803-814.

KlaAssen, M., and R. Drent. 1991. An analysis of hatchling resting metabolism: In search of ecological correlates that explain deviations from allometric relations. Condor 93:612-629.

KlaAssen, M., Å. Lindström, and R. Zijlstra. 1997. Composition of fuel stores and digestive limitations to fuel deposition rate in the long-distance migratory Thrush Nightingale Luscinia luscinia. Physiological Zoology 70:125-133.

Lovegrove, B. G. 1996. The low basal metabolic rates of marsupials: The influence of torpor and zoogeography. Pages 141-151 in Adaptations to the Cold (F. Geiser, A. J. Hulbert, and S. C. Nicol, Eds.). Tenth International Hibernation Symposium, University of New England Press, Armidale, Australia.

McNAB, B. K. 2001. Energetics of toucans, a barbet, and a hornbill: Implications for avian frugivory. Auk 118:916-933.

Piersma, T., AND Å. Lindström. 1997. Rapid reversible changes in organ size as a component of adaptive behaviour. Trends in Ecology and Evolution 12:134-138.

Rahn, H., C. V. Paganelli, and A. Ar. 1975. Relationship of avian egg weight to body weight. Auk 92:750-765.

RickLEFS, R. E. 1976. Growth rates of birds in the humid New World tropics. Ibis 118:179-207.
SChiEltz, P. C, AND M. A. MurPhy. 1997. The contribution of insulation changes to the energy cost of avian molt. Canadian Journal of Zoology 75: 396-400.

Stanback, M., D. S. Richardson, C. Boix-HinZen, AND J. Mendelsohn. 2002. Genetic monogamy in Monteiro's Hornbill, Tockus monteiri. Animal Behaviour 63:787-793.

Stienen, E. W. M., And A. BRenninkmeijer. 1999. Keep the chicks moving: How Sandwich Terns can minimize kleptoparasitism by Black-headed Gulls. Animal Behaviour 57:1135-1144.

Thiollay, J.-M. 1991. Food limitation in tropical bird populations. Pages 1576-1583 in Acta XX Congressus Internationalis Ornithologici (B. D. Bell, Ed.). New Zealand Ornithological Congress Trust Board, Wellington.

Weathers, W. W. 1979. Climatic adaptations in avian standard metabolic rate. Oecologia 42: 81-89.

Weathers, W. W. 1996. Energetics of postnatal growth. Pages 461-496 in Avian Energetics and Nutritional Ecology (C. Carey, Ed.). Chapman and Hall, New York.

WeAthers, W. W. 1997. Energetics and thermoregulation by small passerines of the humid, lowland tropics. Auk 114:341-353.

Weathers, W. W., and R. B. Siegel 1995. Body size establishes the scaling of avian postnatal metabolic rate: An interspecific analysis using phylogenetically independent contrasts. Ibis 137:532-542.

Williams, J. B. 1996. Energetics of avian incubation. Pages 375-416 in Avian Energetics and Nutritional Ecology (C. Carey, Ed.). Chapman and Hall, New York.

Associate Editor: M. Brittingham 